\title{
IMPLEMENTING SMART GREEN BUILDING ARCHITECTURE TO RESIDENTIAL PROJECT BASED ON KAOHSIUNG, TAIWAN
}

\author{
LIU, K. S. ${ }^{1}-$ LIAO, Y. T. ${ }^{1}-$ HSUEH, S. L. ${ }^{2 *}$ \\ ${ }^{1}$ Department of Interior Design, Tung Fang Design Institute, Taiwan \\ ${ }^{2}$ Graduate Institute of Cultural and Creative Design, Tung Fang Design Institute \\ No.110, Dongfang Rd., Hunei Dist., Kaohsiung City 82941, Taiwan (R.O.C.) \\ *Corresponding author \\ e-mail: hsueh.sl@msa.hinet.net; tel: +86-9-328-83292; fax: +86-7-693-9663
}

(Received 12 $2^{\text {th }}$ Aug 2016; accepted $15^{\text {th }}$ Nov 2016)

\begin{abstract}
In order to be in line with the thought of the general public with regard to the implementation of Green Architecture on Smart Residential Project, this study is based on the implementation of the Smart Green Architecture of congregate residual buildings in Kaohsiung as the main strategic promotion topic. In addition, this study realized the collection and consolidation of Smart Green Building promotion policy worldwide and carried out comparative analyses of both domestic and oversea Smart/green residential building's energy saving technology. Furthermore, we consolidated 9 major topics and relevant 38 technical methods on residential environment ecosystem, daily passive energy-saving, daily proactive energy-saving, healthy indoor environment, community waste water and garbage treatment, smart door security management, smart environmental monitor system, smart health management, and smart entertainment sharing. Moreover, the application of Likert-type scale is to obtain significant information and to investigate the perception for both construction supplier and general public on the implementation of Smart Green Building Architecture of Residential Project. It simultaneously explained the importance of pro-environmental which results from the implementation of Smart Green Building Architecture. This also assists the promotion of the localized Smart Green Residential Architecture policy.
\end{abstract}

Keywords: smart residential, smart architecture, green architecture, Likert-type scale, pro-environmental

\section{Introduction}

The architecture industry has been recognized with high pollution and high energy consumption and is an environmental unfriendly industry. The Green Architecture is an effective practical method to improve the environmental damages caused by the architecture industry (Hsueh, 2013, 2015; Zhao et al., 2015). Green Architecture not only involves issues such as green design, green procurement, green construction skill and legal matters but also affects the overall skill set of the architecture industrial chain and users' habituation (Goralnik and Nelson, 2011; Logman et al., 2015) and acceptance issues (Brunhaver et al., 2012; McLaughlan, 2007). Therefore, architecture design, procurement, construction and management are only confined by state-owned constructions. Moreover, Green Architecture regulations lack a mandatory restriction on privately-owned projects. Therefore, the implementation of Green Architecture and Smart Architecture in Taiwan is unable to identify the effectiveness of energy-saving and carbon emission reduction as well as reduction in environmental pollution. Therefore, the architecture industry in Taiwan is still an industry which emits high $\mathrm{CO}_{2}$, and high $\mathrm{CO}_{2}$, causes issues such as environmental damage, greenhouse effect, abnormal weather, and climate change etc. (Khan et al., 2016; Heidari and Pearce, 2016). 
As a result, we shall not neglect climate change issues. The nature of Green Architecture is a behavior of mitigation to climate changes (Nema et al., 2012). An agreement on the reduction of $\mathrm{CO}_{2}$ emission has been signed during the Climate Summit 2015 which took placed in Paris. As a result, the architecture industry shall actively face the subject of green transformation. To this extent, this helps to prevent the operational impact on business and overall economic status if carbon emission taxation takes place in the future (Rafindadi, 2016).

The current project on the implementation of Smart Green Architecture in Taiwan is the Green Architecture technology from the past and implement the smart control technology in the mind of the life style of the general public. In addition, we can apply the result of advanced technology software and energy-saving Green Architecture to achieve the promotion of the Smart Green Architecture industry (Chen and Kang, 2016; da Silva et al., 2015; GhaffarianHoseini et al., 2013; Toure et al., 2015; Mihelcic et al., 2007). Furthermore, we should provide health and safety, convenience and comfortability, the energy-saving and environmental-friendly concept to the general public. Moreover, to achieve the goal and the development of technological industry. The promotion of smart and green technologies should be educational in nature, reaching out to a wide range of parties and allowing them to participate in the progress of the technologies (Kua et al., 2002; Hurtado and Hunte, 2007; Pierchala et al., 2016). Therefore, how to customize the policy which would be most suitable for Kaohsiung in promoting Smart Green Architecture and the understanding of construction suppliers and general public's perception towards the policy are the main purpose of this study.

In order for the promotion of the Smart Green Architecture to meet with the thought of the general public, this study has consolidated relevant literatures, proactive energysaving, and passive energy-saving technologies on residential buildings and obtained significant information through the application of the Likert-type scale (Tastle et al., 2005) technique. This approach clarified the perception influence of construction suppliers and general public when implementing Smart Green Architecture into residential projects as well as clarified the importance of pro-environmental during Green Architecture planning.

\section{Literature Review}

The insulation applying on building roofs of a green building architecture (Ozel and Pihtili, 2007) or the compounded materials on the walls and roofs have a direct impact on the comfortability of indoor rooms (Kumar et al., 2013). In addition, the roof of a green building has the most effective result in insulation (Silva et al., 2015; Bevilacqua et al., 2015). Moreover, double facades have natural ventilation effects (Silva et al., 2015; Blanco et al., 2014). Furthermore, comparing with single facades, double facades have empirical thermal comfort (Huckemann et al., 2010). Apart from the above mentioned materials, designs and techniques have a direct impact over green residential buildings. Other factors also include double-layer glass (Sun et al., 2016), Low emissivity glass (LOW-E glass), ventilation design (Belleri et al., 2014) and solar power systems (DeVault et al., 2014) etc. Solar power systems and ventilation designs in particular utilize the advantage of nature resources based on the geographic environment and are the design factors for a green building project.

The factor which forms proactive energy-saving and passive energy-saving technique of Smart Green architectures in Taiwan is classified into 14 categories. A Low Smart 
Green Architecture in particular focuses on the structure first, then structure and facility. The four main building structures consist of insulated roof, exterior insulated wall, concrete floors, and roof eaves. The 6 sub-structures consists of sunroof, large number of windows, LOW-E glass, intensified shading effect by plantation, green roof, and ventilation design. There are 4 building facilities which consist of rainwater storage system, energy-saving light, solar power plate and low Volatile Organic Compound (VOCs) coating. In addition, there are 9 categories for high Smart Green Architectures which include timers for ventilation fan in the shower room, multi-split air conditioner, solar power system, programmable temperature control system, and photovoltaics sensing system. The above mentioned items are currently the most significant factors for the promotion of Smart Green Architectures in Taiwan.

The Ministry of Interior in Taiwan has carried out research on the topic of Smart Green Architecture since 1992 and in 2002 the Ministry of Interior has further promoted the concept of Smart residential space, and have started Smart Architecture Mark evaluation system to quantify the research. The application handbook of Smart Architecture Mark has been published in 2003 and it officially accepted the application of Smart Architecture Mark in 2004. In addition, in order to achieve the promotion and implementation of Smart Green Architectures for the smart emerging industry which carried out by the Ministry of Interior in Taiwan, the application of green Architecture and Smart equipment have been enhanced and expanded. This aims to meet the future lifestyle and environmental requirement of Smart Architectures and to achieve the promotion and development of the Smart Green Architecture industry. Four major promotional policies (total of 28 measures) were introduced and implemented between 2010 to 2015. The Smart Green Architecture promotion policy emphasizes on the environmental quality and ecological factors of residential areas. This consists of the architecture as the main carrier for Smart Green Architecture and implements Green Architecture design, high Smart technology, and the application of materials and products so as to provide health and safety, convenience and comfortability, the energysaving and environmental friendly concept to the general public and proceed with the research of innovative technologies, products, systems and services. It is expected to establish production, lifestyle, and ecology to achieve high quality living environment and to simultaneously raise industrial competitiveness and grasp large innovative industrial business opportunities. To increase residential living environment. Moreover, it is expected to promote the development of technology industry.

\section{Information classification and comparison}

This study has selected 10 oversea Smart green residential buildings as a case study and has classified the findings in Table 1 based on proactive energy-saving and passive energy-saving. The comparison of the design factors for oversea Smart green residential buildings is shown as follows.

From the above comparison table of design factors for oversea smart green residential buildings (Table 1), it indicated that the factors which affect the thermal insulation and shading are: insulated roof, insulated exterior wall, roof, and LOW-E glass. The table also indicates that the factors which affect the ventilation are: large number of window and the design of the ventilation system. The factors which affect energy-saving are: rainwater storage system, energy-saving lighting, solar power system, and programmable temperature control system. The factors which reduce the impact on health related issues is low VOCs coating. 
Table 1. Comparison table of design factors for oversea Smart green residential buildings

\begin{tabular}{|c|c|c|c|c|c|c|c|c|c|c|c|c|c|c|c|c|c|c|c|c|c|c|c|}
\hline \multirow[b]{3}{*}{$\begin{array}{l}\text { Item } \\
\text { Description }\end{array}$} & \multicolumn{14}{|c|}{ Passive energy-saving } & \multirow{2}{*}{\multicolumn{9}{|c|}{$\begin{array}{c}\text { Proactive energy saving } \\
\text { Equipment }\end{array}$}} \\
\hline & \multicolumn{4}{|c|}{$\begin{array}{l}\text { Primary } \\
\text { structure }\end{array}$} & \multicolumn{6}{|c|}{ Secondary structure } & \multicolumn{4}{|c|}{ Equipment } & & & & & & & & & \\
\hline & 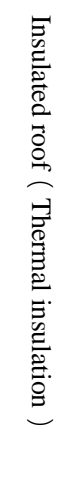 & 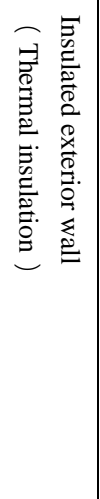 & 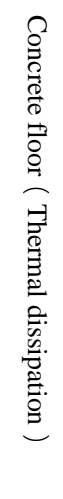 & 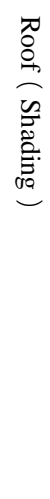 & 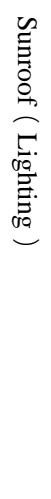 & 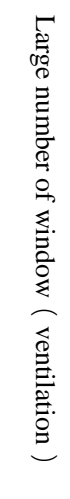 & 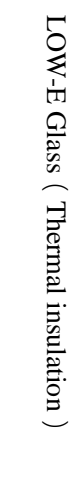 & 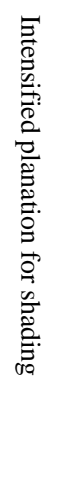 & 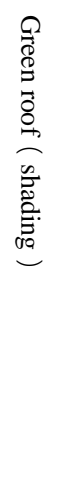 & 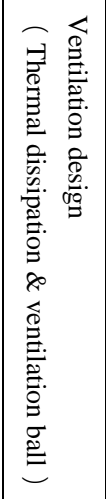 & 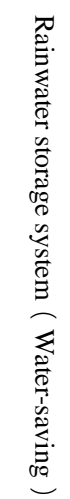 & 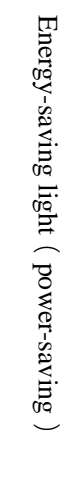 & 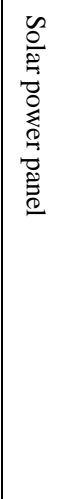 & 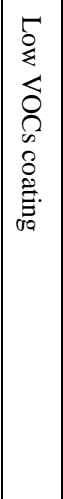 & 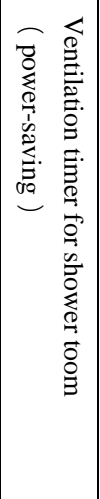 & 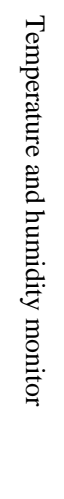 & 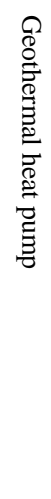 & 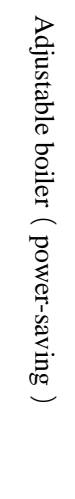 & 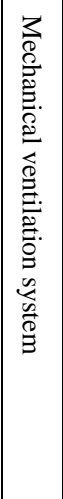 & 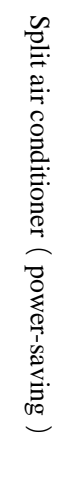 & 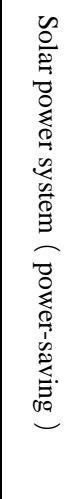 & 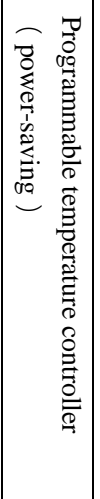 & 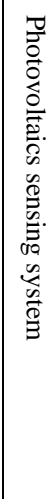 \\
\hline $\begin{array}{l}\text { Benavieds } \\
\text { Residence } \\
\end{array}$ & $\sqrt{ }$ & $\sqrt{ }$ & & $\sqrt{ }$ & & & $\sqrt{ }$ & & & & $\sqrt{ }$ & $\sqrt{ }$ & $\sqrt{ }$ & $\sqrt{ }$ & $\sqrt{ }$ & & & & & & & $\sqrt{ }$ & \\
\hline Black Residence & & $\sqrt{ }$ & $\sqrt{ }$ & & & & $\sqrt{ }$ & $\sqrt{ }$ & & & $\sqrt{ }$ & & $\sqrt{ }$ & $\sqrt{ }$ & $\sqrt{ }$ & & $\sqrt{ }$ & & & & & & \\
\hline Capitol Court Home & $\sqrt{ }$ & $\sqrt{ }$ & & $\sqrt{ }$ & & $\sqrt{ }$ & $\sqrt{ }$ & & & & $\sqrt{ }$ & & & $\sqrt{ }$ & $\sqrt{ }$ & & & $\sqrt{ }$ & $\sqrt{ }$ & & & $\sqrt{ }$ & \\
\hline District Home & & $\sqrt{ }$ & & $\sqrt{ }$ & & $\sqrt{ }$ & & & & & $\sqrt{ }$ & $\sqrt{ }$ & & $\sqrt{ }$ & & & & & & $\sqrt{ }$ & $\sqrt{ }$ & $\sqrt{ }$ & \\
\hline Madill & $\sqrt{ }$ & $\sqrt{ }$ & & $\sqrt{ }$ & & $\sqrt{ }$ & $\sqrt{ }$ & $\sqrt{ }$ & & & $\sqrt{ }$ & & & $\sqrt{ }$ & & & $\sqrt{ }$ & & & & & $\sqrt{ }$ & \\
\hline BedZed & $\sqrt{ }$ & $\sqrt{ }$ & & & & & & & $\sqrt{ }$ & $\sqrt{ }$ & $\sqrt{ }$ & & & $\sqrt{ }$ & & $\sqrt{ }$ & & & & & $\sqrt{ }$ & & \\
\hline Berliner Str42-48 & & & & & $\sqrt{ }$ & $\sqrt{ }$ & & & & & & & & & & & $\sqrt{ }$ & & & & & $\sqrt{ }$ & \\
\hline Ferrier & $\sqrt{ }$ & $\sqrt{ }$ & & $\sqrt{ }$ & $\sqrt{ }$ & $\sqrt{ }$ & $\sqrt{ }$ & & & & $\sqrt{ }$ & $\sqrt{ }$ & & $\sqrt{ }$ & & & & & & & $\sqrt{ }$ & $\sqrt{ }$ & $\sqrt{ }$ \\
\hline Bluff Dale & $\sqrt{ }$ & $\sqrt{ }$ & & $\sqrt{ }$ & & $\sqrt{ }$ & & & & & & & & $\sqrt{ }$ & & & & & & & $\sqrt{ }$ & $\sqrt{ }$ & \\
\hline Parker County & $\sqrt{ }$ & $\sqrt{ }$ & & $\sqrt{ }$ & & $\sqrt{ }$ & $\sqrt{ }$ & & & & $\sqrt{ }$ & $\sqrt{ }$ & & $\sqrt{ }$ & & & & & & & $\sqrt{ }$ & $\sqrt{ }$ & \\
\hline
\end{tabular}


In addition, there are five residential projects which were been certified by Smart Architecture Mark during 2009 to 2013. This study consolidated relevant information on Smart design technology for three residential projects. The consolidation consists of 4 items of door access management, 4 items of environmental monitoring control, 2 items of health management, 2 items of entertainment sharing with a total of 12 items for the design technology of smart residential projects. Table 2 shows the consolidated items discussed above for those three projects:

Table 2. Items of the smart building design technology for those three projects

\begin{tabular}{|c|c|}
\hline Category & Content \\
\hline $\begin{array}{l}\text { Door Access } \\
\text { Management }\end{array}$ & $\begin{array}{l}\text { 1. Handheld information technology device (i.e., cellphone), } \\
\text { auto connected security door (electronic security) } \\
\text { 2. Access Recognition System (i.e., fingerprint, eyes) } \\
\text { 3. IP cloud home security system (monitoring home status at } \\
\text { all time) } \\
\text { 4. Information and communication connected within the } \\
\text { community via internet (monitoring community area status } \\
\text { at all time) }\end{array}$ \\
\hline $\begin{array}{l}\text { Environmental } \\
\text { Monitoring } \\
\text { System }\end{array}$ & $\begin{array}{ll}\text { 5. } & \text { Smart LED lighting } \\
\text { 6. } & \text { Set up temperature humanity sensing device } \\
\text { 7. } & \text { Smart air-conditioner and smart power control system } \\
\text { 8. } & \text { Hazardous gas detector (i.e., carbon monoxide, carbon } \\
\text { dioxide) }\end{array}$ \\
\hline $\begin{array}{l}\text { Health } \\
\text { Management }\end{array}$ & $\begin{array}{l}\text { 9. Body status measurement (data transmitted and saved to } \\
\text { cellphone) } \\
\text { 10. Home health-care monitor (transmitting data direct to the } \\
\text { health care center) }\end{array}$ \\
\hline $\begin{array}{l}\text { Entertainment } \\
\text { sharing }\end{array}$ & $\begin{array}{l}\text { 11. Provide easy card function on a cellphone, and use it as a } \\
\text { door access device and payment for bus fees } \\
\text { 12. Platform for entertainment media such as digital photo } \\
\text { frame, desktop interaction device, and to provide family } \\
\text { sharing, viewing for a better relationship. }\end{array}$ \\
\hline
\end{tabular}

\section{Research method and questionnaire}

\section{Likert-type scale}

The Likert-type scale was established by Rensis Likert and is a measure of psychological reactions. It is commonly used in the form of questionnaire. This method is widely used in most of the research as the core measurement of psychological reactions. The advantage of applying the Likert scale is that when the interviewee answers the questions, it enables participants to be more specific to the level of acceptance (Weijters et al., 2016; William et al., 2005). 


\section{Data preparation}

This study has consolidated relevant literatures with regard to smart residential green buildings and categorized case studies from oversea, and the study carried out by the Ministry of Interior, Taiwan on the technology of green architecture and smart residential building as well as regulations on the exercise of autonomy of Kaohsiung green architecture as the reference when designing the questionnaire. Moreover, Likerttype scale can also be applied when designing the questions in order to enable participants to be more specific to the level of acceptance. In addition, in order to prevent an ineffective questionnaire data caused by technical terms used in the questionnaire and to increase the effectiveness of the questionnaire data, a diagram of smart residential green building has been illustrated in 3D format. Per Figure 1, all the technical terms were transformed into a diagram which would be easily understood by most participants.

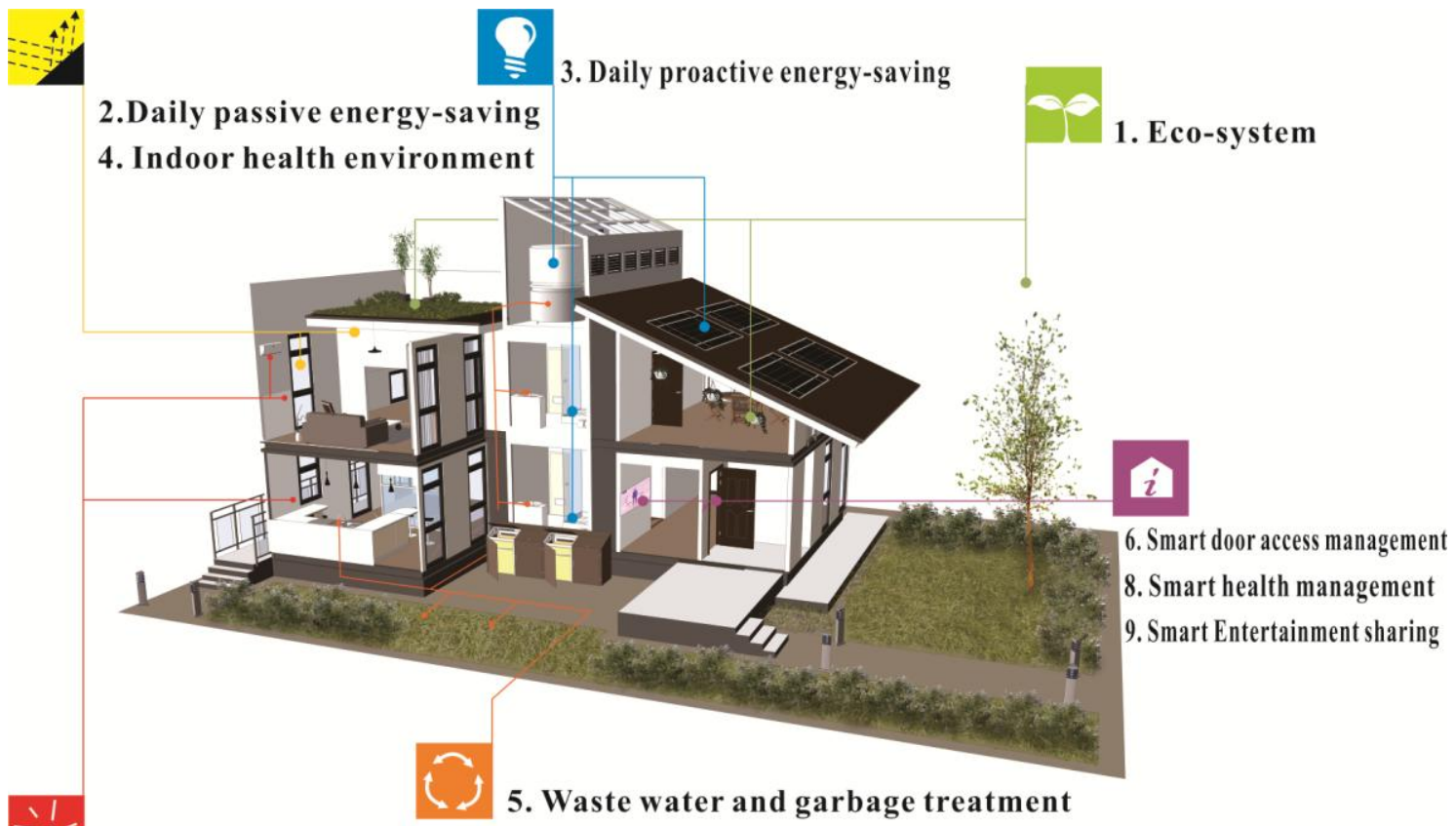

7. Smart environmental monitoring management

Figure 1. 3D diagram of a smart residential green building

This study distributed 40 copies of questionnaire to practitioners, 73 copies to the general public and received 32 copies of effective questionnaire from practitioners and 54 copies of effective questionnaire from the general public.

\section{Investigation on the application of smart green building technology from practitioner}

(1) Gender proportion: 15 male participants (46\%), 17 female participants (54\%)

(2) Age analysis: age 25-30: 3 participants (9\%), age 31 35: 10 participants (31\%), age 36 40: 12 participants (38\%), age 41 45: 4 participants (13\%), age 46 40: 2 participants (6\%), age 50 55: 1 participant (3\%), age 36 40 is the highest investigation group of this study. 
(3) Education qualification: high school or higher education: 1 participant (3\%), undergraduate: 18 participants $(56 \%)$ and postgraduate: $13 \%$ participants $(41 \%)$.

(4) Occupation: architecture: 15 participants (47\%), construction : 4 participants (12\%), others (relevant designers): 13 participants (41\%)

(5) For the questionnaires which have been returned, 32 participants have been in contact with construction development projects of congregate housing designs.

The technique applied for smart green building can be categorized into 9 major areas; these are residential environment eco-system, daily passive energy-saving, daily proactive energy-saving, healthy indoor environment, community waste water and garbage treatment, smart door security management, smart environmental monitor system, smart health management, and smart entertainment sharing. An investigation has been carried out based on these 9 major categories and 32 local architectures or property developer, and construction companies were involved to better understand the technique rating of residential design plans (with the primary focus on congregate housing). The popularity rating method is to prioritize those with highest score starting from point $9,8,7$ and so on.

\section{Investigation on the preference of Kaohsiung citizens with regard to the promotion of smart green building}

(1) Gender proportion: 29 male participants (53.7\%), 25 female participants $(46.3 \%)$

(2) Age analysis: age 30 35: 9 participants (16.7\%), age 36 40: 6 participants (11.1\%), age 41 45: 10 participants (18.5\%), age 46 40: 13 participants (24.1\%), age 51 55: 11 participant (20.4\%), age 56 60: 4 participants (7.4\%), age 61 65: 1 participant (1.9\%)

(3) Education qualification: elementary/junior high school: 4 participants (7.4\%), high school or higher education: 19 participant (35.2\%), undergraduate: 21 participants $(38.9 \%)$ postgraduate: $7 \%$ participants (13\%), PHD: 3 participants $(5.6 \%)$

(4) Income analysis: below \$20,000: 5 participant (9.3\%), \$20,001 40,000: 32 participant (59.3\%), \$40,001 \$60,000: 9 participant (16.7\%), \$60,001 \$80,000: 5 participant $(9.3 \%), \$ 80,001 \sim \$ 100,000: 2$ participant $(3.7 \%)$ and exceed $\$ 100,001$ : 1 participant (1.9\%)

(5) Occupation: public servant: 4 (7.4\%), teacher: 4 (13.0\%), agriculture: 1 (1.9\%), labor: 14 (25.9\%), commercial: 15 (27.8\%), housewife: 2 (3.7\%) and others: 11 $(20.4 \%)$.

The techniques applied for smart green buildings can be categorized into 9 major areas; these are residential environment ecosystem, daily passive energy-saving, daily proactive energy-saving, healthy indoor environment, community waste water and garbage treatment, smart door security management, smart environmental monitor system, smart health management, and smart entertainment sharing. An investigation has been carried out based on these 9 major categories and has taken into the consideration of the preference and factors when considering house purchase. The investigation targeted at participants who are located in Kaohsiung and over the age of 30. Rating method is to priority those with highest score starting from point 9, 8, 7 and 1 being the last. 


\section{Results and Discussion}

\section{Investigation on the application of smart green building technology from practitioners}

According to Figure 2, the analysis result of the questionnaire indicated that the community waste water and the garbage treatment have an average point of 5 which is in the middle. There are 4 items which are above the score of 5 and shall be regarded as the indices of green building techniques. Passive energy-saving has the highest score of 7.35. Residential environment ecosystem is in the second place with the score of 6.81 . In the third place is daily proactive energy-saving and the fourth place is healthy indoor environment. There are 4 items which are below the score of 5 and shall be regarded as the indices of green building techniques. Smart entertainment sharing has the lowest score with 1.63, in the sixth place is smart environmental monitoring system with the score of 3.91, in the seventh place is smart door access management with the score of 3.88 , in the eighth place is smart health management with the score of 3.03. From the above results, we can conclude that out of the 32 participants most of them take into consideration of green building (with the primary focus on congregate housing) more than smart building.

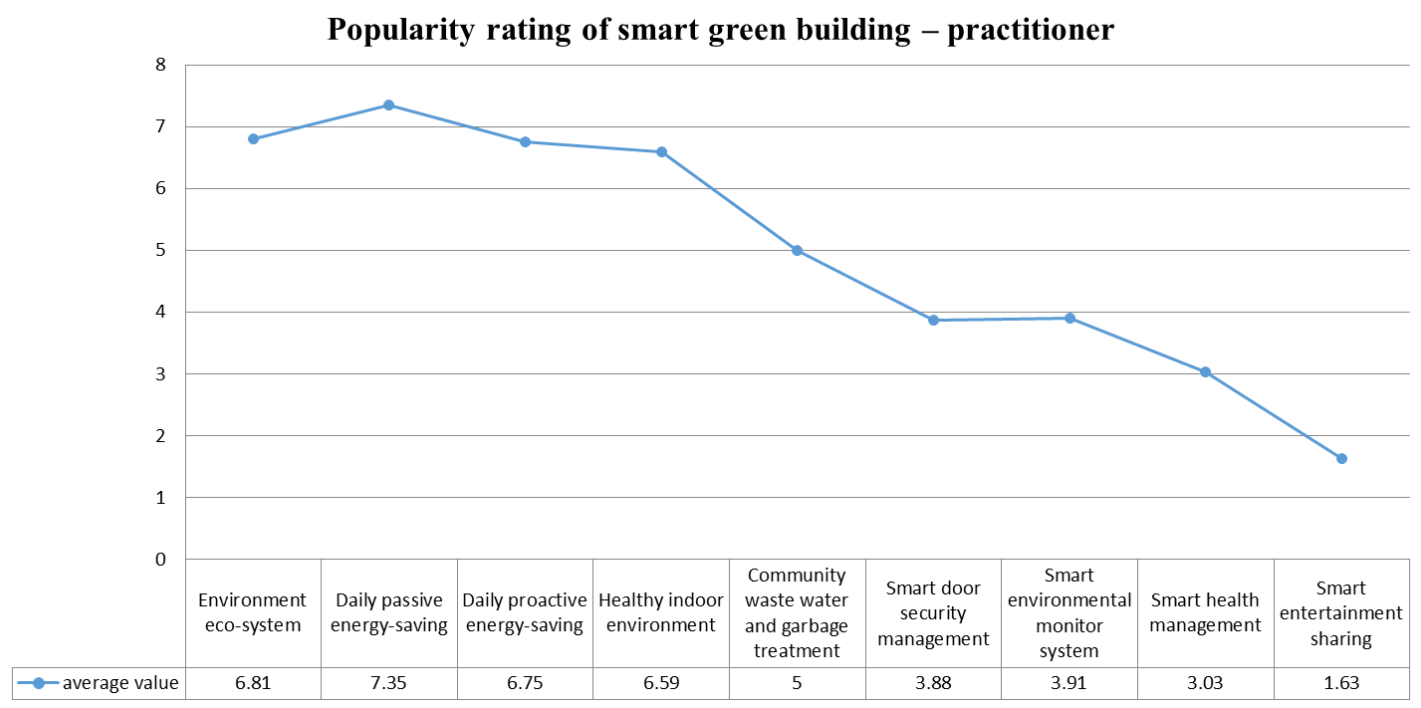

Figure 2. Popularity rating of smart green building - practitioner

The questionnaire pointed out one open-ended question to architecture practitioners. This question is 'are there any recommendations which you would like to provide with regard to the smart green architecture projects which the government is attempting to promote?' The result indicated that cost and subsidy are the two major feedbacks from the private sector. In addition, it is expected to define the market position of smart green architecture in Kaohsiung instead of over-priced smart architecture design. Practitioners have pointed out enhancing privacy, raising awareness to the general public, implementing social benefit policies, providing advices case by case, better use of nature environment of the foundation, considering building and facility separately as a part of the recommendation. 


\section{Investigation on the preference of Kaohsiung citizens with regard to the promotion of smart green building}

According to Figure 3, the analysis result of the questionnaire indicated that smart door access management has an average point of 4.94 which is close to the middle of 5 . There are 5 items which are above the score of 5 . Ecological Residential environment has the highest score of 6.74; in the second place is daily passive energy-saving with the score of 6.52. In the third place is indoor health environment with the score of 6.37 , fourth place is daily proactive energy-saving. The fifth place is community waste water and garbage treatment with the score of 5.69. There are 3 items which are below the score of 5. Smart entertainment sharing has the lowest score with 1.62, in the seventh place is smart environmental monitoring system with the score of 3.91, in the eighth place is smart health management with the score of 2.72. From the above statement we can conclude that a large majority of Kaohsiung citizens take into consideration of green buildings (more than just smart buildings).

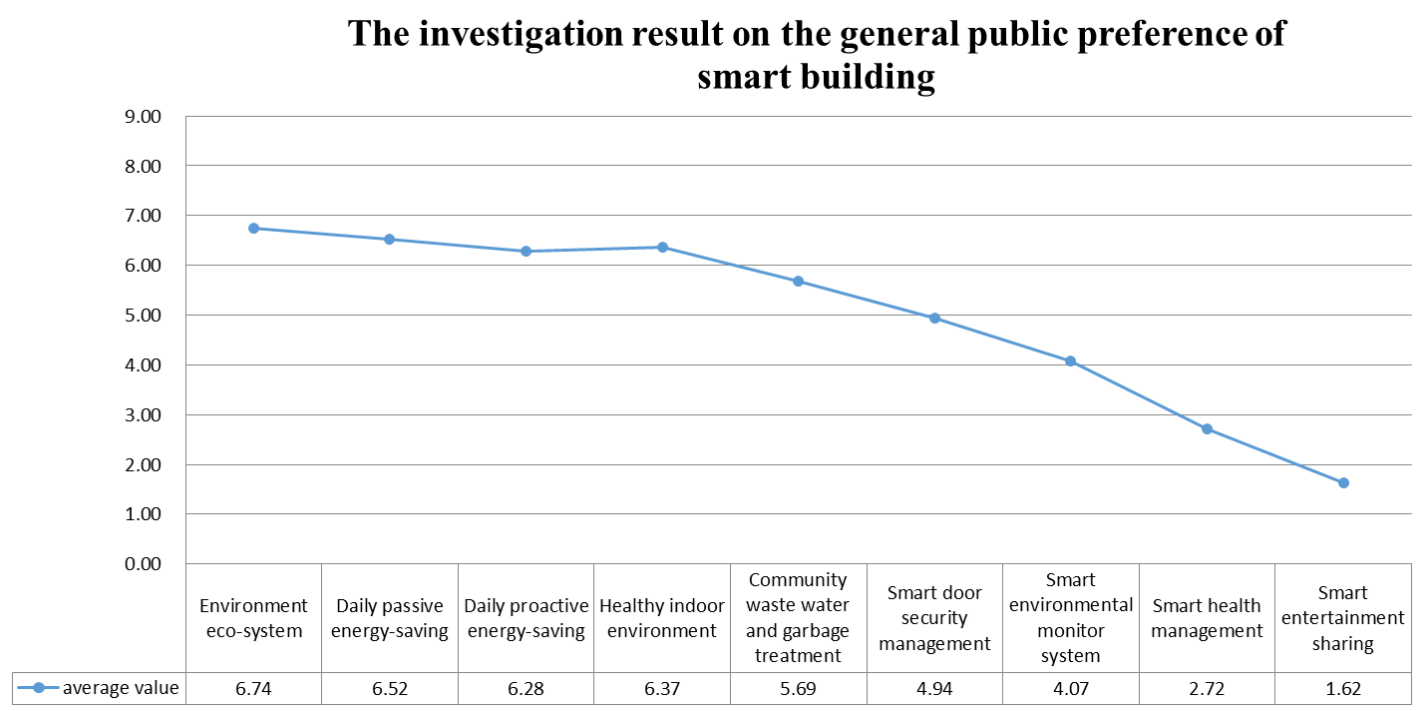

Figure 3. Investigation results on the general public preference of smart buildings

The smart green building preference by different age bracket indicated that the age bracket between 51-65 takes residential environment ecosystem as an important factor and factors such as daily passive energy-saving, daily proactive energy saving, indoor health environment, and community waste water and garbage treatment also have a preference score above four. In general, most of the age brackets have a high acceptance level in green building technology. The acceptance level in smart building technologies is low. However, the result indicated that four smart technologies still has its own market, i.e., age bracket 56-60 takes smart health management as an important factor (5 points); age brackets 30-35 and 36-40 takes smart entertainment sharing as a high preference level (Figure 4).

According to Figure 4, this study took the score of level one (9 major categories) and the score of level two (38 technical methods) to derive Figure 5. As per Figure 5 regardless of the construction consideration from practitioner nor the preference of traditional green building method of the general public, this study recommended Kaohsiung to promote smart green buildings in the order of residential environment 
ecosystem, daily passive energy-saving, daily proactive energy saving, indoor health environment, and community waste water and garbage treatment. These are the five matured categories of low smart green building strategies.

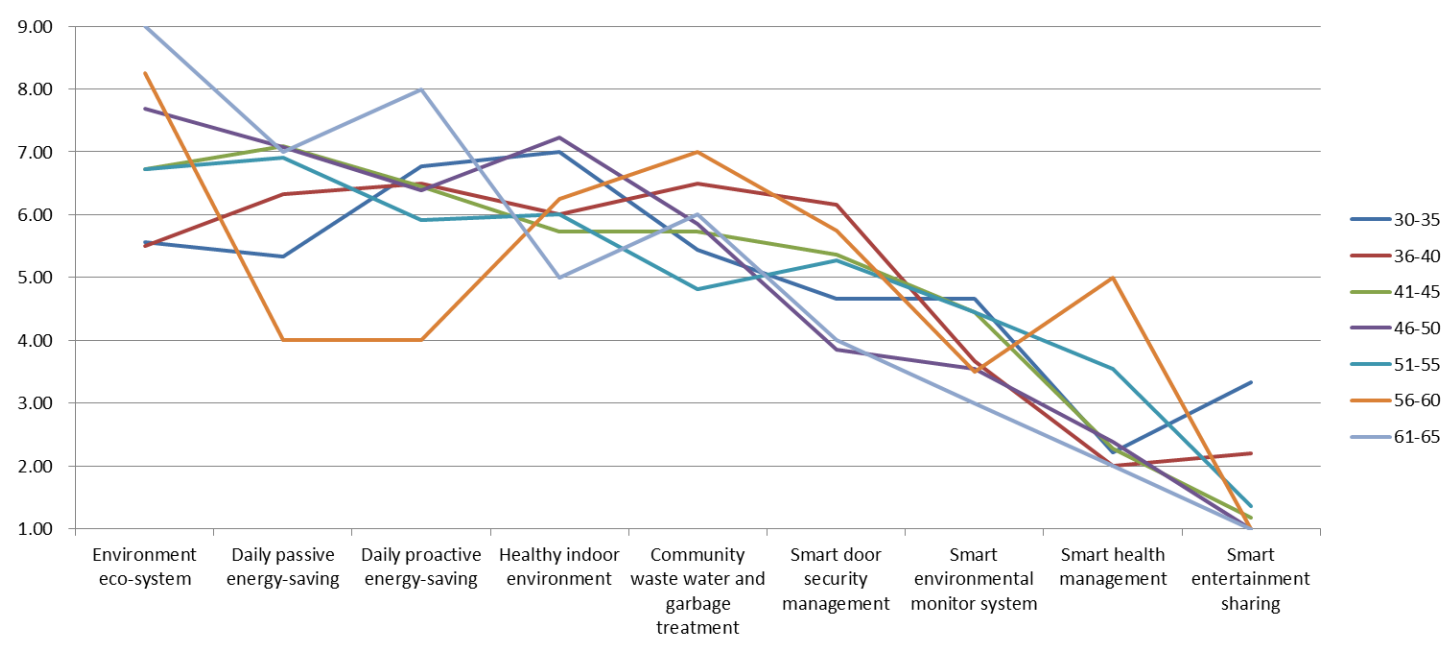

Figure 4. Smart green building preferences by different age brackets

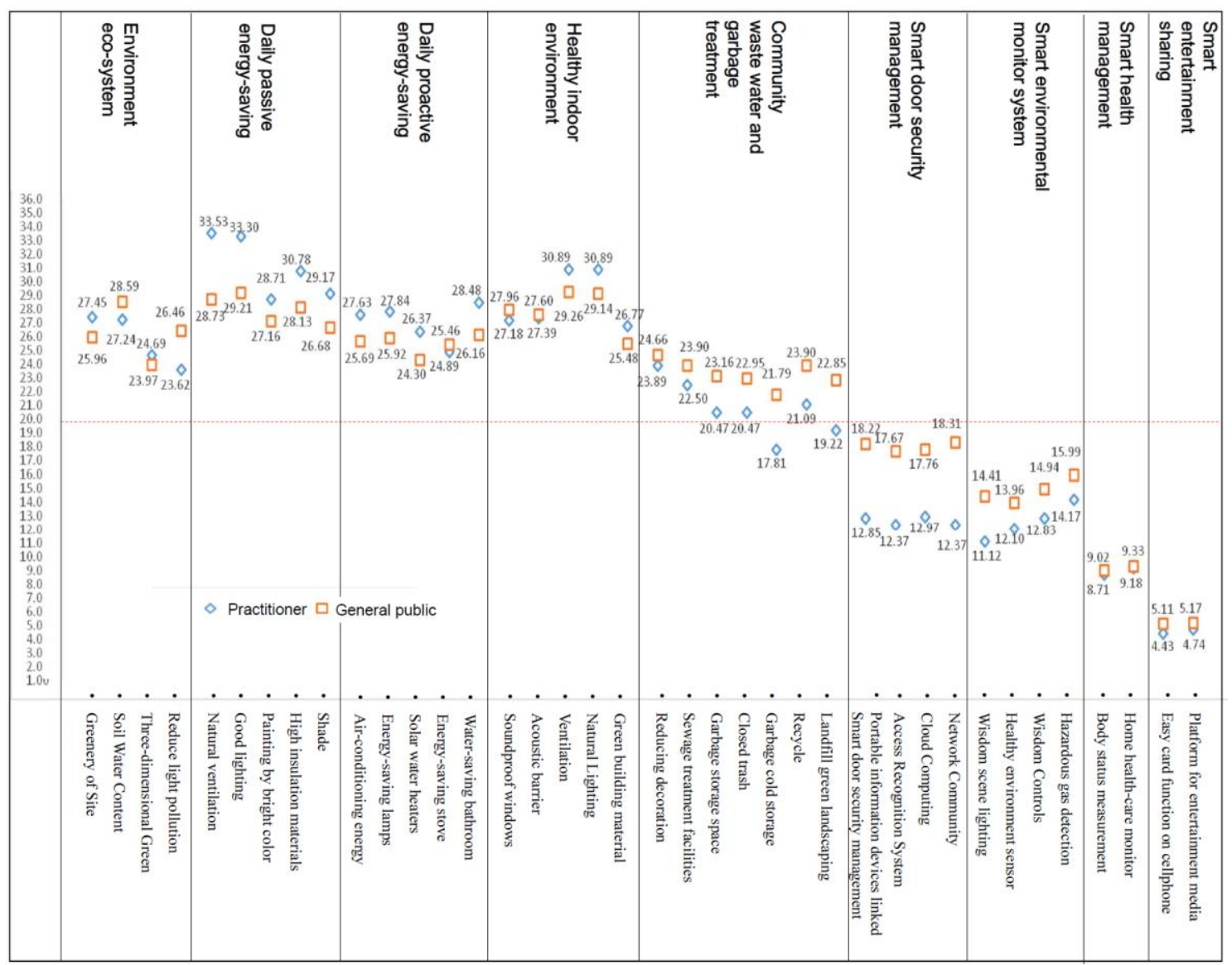

Figure 5. Statistical result of weighted scores from general public and practitioners 


\section{Conclusion}

This study has taken practitioner's construction factors and general public's preferences into consideration so as to derive the below conclusion and recommendation

\section{From design point of view}

Cost and regulation are the major factors from the view of practitioners when considering construction. It is recommended to apply Kaohsiung green building regulations on the exercise of autonomy as the template to generate incentive policies or training programs.

The reason for the low score on high-tech smart design methods is due to the cost factor and the practicality factor. From the score it can be concluded that the future promotion of high-tech smart design technologies shall emphasize on functionality such as safety monitoring, elderly caring, etc. This would assist the promotion and implementation in the event that the general public accepts this recommendation.

In view of the practitioner with regard to smart building regulations, it is still recommended to review the project on a case-by-case basis.

Practitioners emphasized on exterior wall, structure, green, lighting, ventilation, regulation, etc. when planning the design. Therefore, they have disregarded interior design as it is not part of the job description. However, the promotion of green buildings is the combination of both interior and exterior designs, and the integration of resources in order to achieve the most effective result.

\section{Preference of the general public}

The result of the questionnaire survey indicated that the top two significant factors when making purchase of a house are (proactive/passive) energy-saving and indoor health environment.

Despite of the fact that high-tech smart design method score is low, it is still above the point of 3 and this indicated Kaohsiung citizens do not reject the development of high-tech smart buildings. Therefore, cost and practicality factors are not significant when considering a house purchase.

The investigation on age brackets indicated that younger age bracket (30-40) has a higher acceptance level with regard to high-tech.

The environmental education of the implementation of smart green residential shall connect to the general public day-to-day living standard so as to enable the general public to be involved during the promotion stage, for instead, energy-saving, health related topics. Once the value has been created in the mind of the general public, it is more likely for the general public to participate more proactively in the concept of raising smart green residency.

\section{REFERENCES}

[1] Belleri, A., Lollini, R., Dutton, S. M. (2014): Natural ventilation design: An analysis of predicted and measured performance. - Building and Environment 81: 123-138.

[2] Bevilacqua, P., Coma, J., Pérez, G., Chocarro, C., Juárez, A., Solé, C., ... \& Cabeza, L. F. (2015): Plant cover and floristic composition effect on thermal behaviour of extensive green roofs. - Building and Environment 92: 305-316. 
[3] Blanco, J. M., Arriaga, P., Rojí, E., Cuadrado, J. (2014): Investigating the thermal behavior of double-skin perforated sheet façades: Part A: Model characterization and validation procedure. - Building and Environment 82: 50-62.

[4] Brunhaver, S. R., Lande, M., Sheppard, S. D., Edward Carryer, J. (2012): Fostering an enterprising learning ecology for engineers. - International Journal of Engineering Education 28(2): 355.

[5] Chen, C. F., Kang, S. F. (2016): Effects of substrates and plant species on water quality of extensive green roofs. - Applied Ecology and Environmental Research 14(2): 77-91.

[6] da Silva, F. M., Gomes, M. G., Rodrigues, A. M. (2015): Measuring and estimating airflow in naturally ventilated double skin facades. - Building and Environment 87: 292301.

[7] DeVault, T. L., Seamans, T. W., Schmidt, J. A., Belant, J. L., Blackwell, B. F., Mooers, N., ... \& Van Pelt, L. (2014): Bird use of solar photovoltaic installations at US airports: implications for aviation safety. - Landscape and Urban Planning 122: 122-128.

[8] GhaffarianHoseini, A., Dahlan, N. D., Berardi, U., GhaffarianHoseini, A., Makaremi, N., \& GhaffarianHoseini, M. (2013): Sustainable energy performances of green buildings: A review of current theories, implementations and challenges. - Renewable and Sustainable Energy Reviews 25: 1-17.

[9] Goralnik, L., Nelson, M. P. (2011): Framing a philosophy of environmental action: Aldo Leopold, John Muir, and the importance of community. - The Journal of Environmental Education 42(3): 181-192.

[10] Heidari, N., Pearce, J. M. (2016): A review of greenhouse gas emission liabilities as the value of renewable energy for mitigating lawsuits for climate change related damages. Renewable and Sustainable Energy Reviews 55: 899-908.

[11] Hsueh, S. L. (2013): A fuzzy logic enhanced environmental protection education model for policies decision support in green community development. - The Scientific World Journal, 2013.

[12] Hsueh, S. L. (2015): Assessing the effectiveness of community-promoted environmental protection policy by using a Delphi-fuzzy method: A case study on solar power and plain afforestation in Taiwan. - Renewable and Sustainable Energy Reviews 49: 1286-1295.

[13] Huckemann, V., Kuchen, E., Leão, M., Leão, É. F. (2010): Empirical thermal comfort evaluation of single and double skin facades. - Building and Environment 45(4): 976982.

[14] Hurtado, O., Hunte, C. (2007): Educating engineers in sustainable energy development: an interdisciplinary approach. - International Journal of Engineering Education 23(2): 266-275.

[15] Khan, S. A. R., Zaman, K., Zhang, Y. (2016): The relationship between energy-resource depletion, climate change, health resources and the environmental Kuznets curve: Evidence from the panel of selected developed countries. - Renewable and Sustainable Energy Reviews 62: 468-477.

[16] Kua, H. W., Lee, S. E. (2002): Demonstration intelligent building-a methodology for the promotion of total sustainability in the built environment. - Building and Environment 37(3): 231-240.

[17] Kumar, A., Suman, B. M. (2013): Experimental evaluation of insulation materials for walls and roofs and their impact on indoor thermal comfort under composite climate. Building and Environment 59: 635-643.

[18] Logman, P., Kaper, W., Ellermeijer, T. (2015): Evaluation of the learning process of students reinventing the general law of energy conservation. - Eurasia Journal of Mathematics, Science \& Technology Education 11(3): 479-504.

[19] McLaughlan, R. G. (2007): Instructional strategies to educate for sustainability in technology assessment. - International Journal of Engineering Education 23(2): 201-208. 
[20] Mihelcic, J. R., Eatmon, T. D., Harris, R. A., Muga, H. E. (2007): Engineering sustainable construction materials for the developing world: a meta-discipline approach to engineering education. - International Journal of Engineering Education 23(6): 11161125 .

[21] Nema, P., Nema, S., Roy, P. (2012): An overview of global climate changing in current scenario and mitigation action. - Renewable and Sustainable Energy Reviews 16(4): 2329-2336.

[22] Ozel, M., Pihtili, K. (2007): Investigation of the most suitable location of insulation applying on building roof from maximum load levelling point of view. - Building and Environment 42(6): 2360-2368.

[23] Pierchala, Ł., Sierka, E., Trzaski, L., Bondaruk, J., Czuber, B. (2016): Evaluation of the suitability of anthropogenic reservoirs in urban space for ecological restoration using submerged plants (upper silesia, poland). - Applied Ecology and Environmental Research 14(1): 277-296.

[24] Rafindadi, A. A. (2016): Does the need for economic growth influence energy consumption and $\mathrm{CO}_{2}$ emissions in Nigeria? Evidence from the innovation accounting test. - Renewable and Sustainable Energy Reviews 62: 1209-1225.

[25] Silva, C. M., Flores-Colen, I., Coelho, A. (2015): Green roofs in Mediterranean areasSurvey and maintenance planning. - Building and Environment 94: 131-143.

[26] Sun, Y., Wu, Y., Wilson, R., Sun, S. (2016): Thermal evaluation of a double glazing façade system with integrated Parallel Slat Transparent Insulation Material (PS-TIM). Building and Environment 105: 69-81.

[27] Tastle, W. J., Russell, J., Wierman, M. J. (2005): A new measure to analyze student performance using the Likert scale. - In Proceedings of the 22nd annual conference on Information Systems Education (ISECON) (p. 2142).

[28] Toure, D., Ge, J., Zhou, J. (2015): Spatial patterns of tree species number in relationship with the local environmental variations in karst ecosystem. - Applied Ecology and Environmental Research 13(4): 1035-1054.

[29] Weijters, B., Baumgartner, H., Geuens, M. (2016): The Calibrated Sigma Method: An Efficient Remedy for Between-Group Differences in Response Category Use on Likert Scales. - International Journal of Research in Marketing. DOI: 10.1016/j.ijresmar.2016.05.003

[30] Zhao, D. X., He, B. J., Johnson, C., Mou, B. (2015): Social problems of green buildings: From the humanistic needs to social acceptance. - Renewable and Sustainable Energy Reviews 51: 1594-1609. 